\title{
振動回転子による振動エネルギー回生の試み*
}

\author{
佐 藤 勇 - $^{* 1}$, 長 嶺 拓 夫 $^{* 2}$, 安 藤 芳 晃 ${ }^{* 3}$
}

\section{Study on Energy Conversion from Vibrational to Rotational Energy by an Oscillatory Rotor}

\author{
Yuichi SATO*4, Takuo NAGAMINE and Yoshiaki ANDO \\ ${ }^{* 4}$ Department of Mechanical Engineering, Saitama University, \\ 255 Shimo-okubo, Sakura-ku, Saitama-shi, Saitama, 338-8570 Japan
}

\begin{abstract}
This paper describes experimental and analytical study on energy conversion from vibrational energy to rotational one by an oscillatory rotor, which will rotate in one direction when it is oscillated. The characteristics of motion of an oscillatory rotor on a vibrating table are investigated experimentally. Consequently, for suitable range of exciting frequency, an oscillatory rotor rotates at an approximately constant speed. The fundamental mechanism of rotation is that the vertical vibration induces parametric oscillation of an oscillatory rotor. Then the characteristic of an oscillatory rotor converts shaking motion into rotational motion in turn.
\end{abstract}

Key Words: Energy Conversion, Parametric Excitation, Unidirectional Rotation, Euler's Equations of Motion of Rigid Body, Vibration

\section{1. 緒 論}

我々の身のまわりの至るところで振動は発生してい る. 例えば，振動は機械などが作動するときにも発生 するが，海面波や地震などの自然界にも多く存在して いる. 機械などの振動は，敬遠されることが多いが， 振動エネルギーを有効なエネルギーに変換可能であれ ば，身近なエネルギー源として有効利用も考えられる.

セルト石の代表的な形状は，棈円体を長手方向に切 断したものである(1)〜(3). 曲面の対称軸が，物体の慣 性主軸とわずかにずれている，そのため，曲面側が，

下となるように床へ置き, 振動を与えると, 一方向の 回転をする.

本研究では，セルト石と同様な運動特性を有するも のを振動回転子と呼ぶことにする. 振動回転子の基本 的な運動特性を前報で検討した ${ }^{(4)}$. 本研究では，振動 回転子に振動を与え続けることで，回転し続けること が可能ではないかと考え, 振動回転子に振動を与えた ときの運動特性を実験的・理論的に調べ，振動を回転 運動に変換することの可能性について検討している.

* 原稿受付 2004 年 12 月 24 日.

*1 正員, フェロー, 埼玉大学工学部(业338-8570さいたま市桜 区下大久保 255).

*2 正員, 埼玉大学工学部.

*3 埼玉大学大学院理工学研究科.

E-mail : ysato@mech.saitama-u.ac.jp

\section{2. 主な記号}

$$
\begin{aligned}
A_{e x} & : \text { 加振振幅 } \\
f_{e x} & : \text { 加振振動数 }\left(\omega_{e x}=2 \pi f_{e x}\right) \\
\mathrm{P}, \mathrm{Q}, \mathrm{R} & : \text { 振動回転子の } 3 \text { 本の脚 }(\text { 図 } 1 \text { 参照 }) \\
S & : \text { 図 } 1 \text { 参照 } \\
\beta & : \text { 回転角 }(\text { 図 } 3 \text { 参照 }) \\
\tau & : \text { 振動回転子の運動周期 } \\
\tau_{e x} & \text { 加振周期 }\left(=1 / f_{e x}\right) \\
\omega & : \text { 振動回転子の運動の角振動数 }(=2 \pi / \tau) \\
\Omega & : \text { 回転角速度 }(=\mathrm{d} \beta / \mathrm{d} t)
\end{aligned}
$$

\section{3. 実 験}

試作した振動回転子の概略図を図 1 に示す．振動回 転子には，先端のとがった 3 本の脚 $\mathrm{P}, \mathrm{Q}, \mathrm{R}$ が等間 隔 $\left(L_{1}=10.0 \mathrm{~mm}, L_{2}=3.5 \mathrm{~mm}\right)$ に取り付けられている. 中央の脚 $\mathrm{Q}$ は両端の脚 $\mathrm{P}, \mathrm{R}$ よりも $L_{3}=0.3 \mathrm{~mm}$ だけ 長い. 脚 $\mathrm{Q}$ の先端 $\mathrm{C}$ から重心 $\mathrm{G}$ までの距離は, $H=8.7 \mathrm{~mm}$ である. 振動回転子の総質量 $M=32.7 \mathrm{~g}$ で, 図に示すように質量 $m=4.7 \mathrm{~g}$ の集中質量 4 個が取り 付けられている. 慣性モーメントを変化させるため, 集中質量間の距離 $2 S$ を 10〜80 mm まで変えた. 図 1 に示すように中央の脚 $\mathrm{Q}$ の先端 $\mathrm{C}$ を振動回転子に固

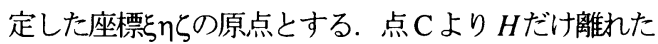




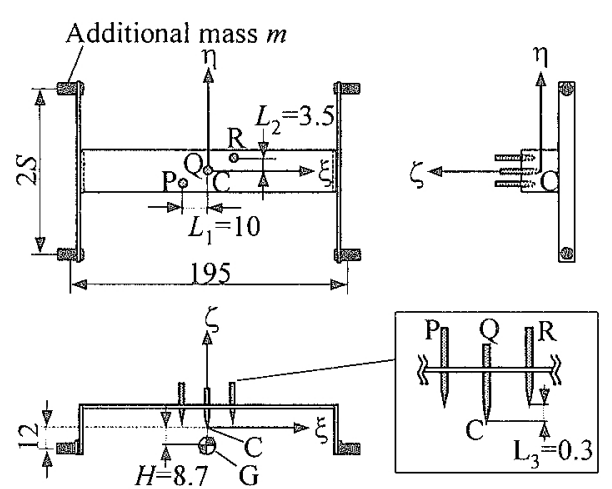

Fig.1 Schematic of an oscillatory rotor

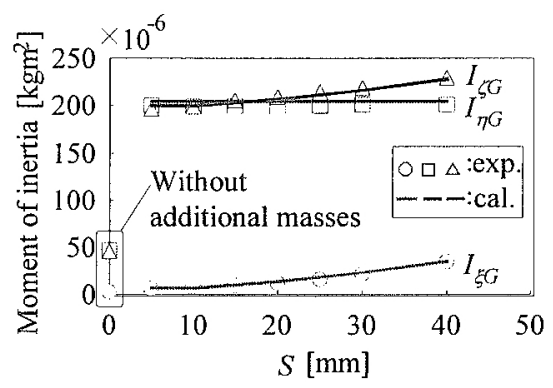

Fig.2 Effect of $S$ on moments of inertia

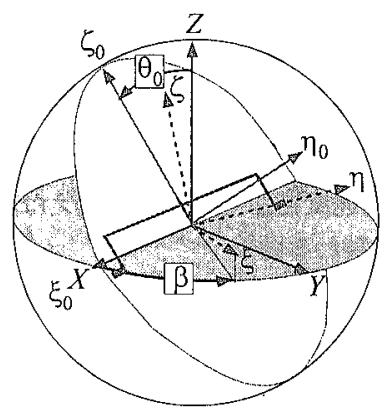

Fig.3 Coordinate systems

( $X Y Z$ : fixed in space, $\xi \eta \zeta$ : fixed in the body)

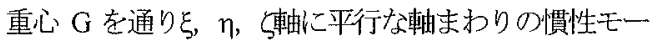
メントを $I_{\xi G}, I_{\eta G}, I_{\zeta G}$ とし，これらをSに対して図2 に示す， $S$ が減少すると当然であるが， $I_{\zeta G}$ と $I_{\zeta G}$ まわ りの慣性モーメントは減少する. $S=0 \mathrm{~mm}$ の位置に示 す值は集中質量を外したときゆ慣性モーメントである.

振動回転子の運動特性を定量的に評価するために, 以下の実験を行った. 振動回転子に初期角速度を精度 よく与えることは難しいので，初期角速度はぜロとし，

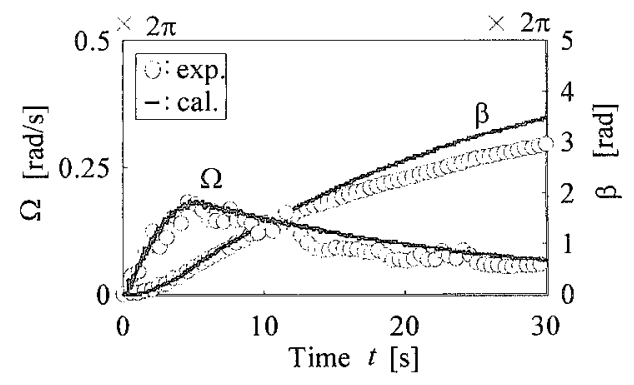

Fig.4 Transient motion of an oscillatory rotor without excitation $\left(S=40 \mathrm{~mm}, \theta_{0}=30 \mathrm{deg}\right.$, $f_{e x}=0 \mathrm{~Hz}, A_{e x}=0 \mathrm{~mm}$ )

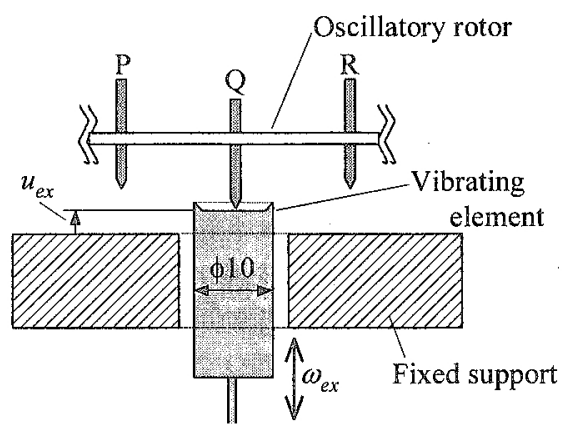

Fig.5 Enlarged schematic view of three legs of an oscillatory rotor and the tip of a vibrator $\left(u_{e x}=A_{e x} \sin \omega_{e x} t\right)$

図3に示すように軸まわりに振動回転子を $\theta_{0}$ 傾けて, 脚 $\mathrm{P}$ 先端のみが台と接するように支持し，支持を取り 去った後の振動回堭子の運動を観察した. 初め, 軸 (図 $3 の \xi_{0}$ 軸)を空間に固定された $X$ 軸と一致させ，あ る時間経ったときの軸を $X Y$ 平面へ正射影し，その $X$ 軸からの回転角を防るる. 防，上から見て反时計 まわりを正とする．実験では $S$ をパラメータとして, 队に及ぼす影響を調べた. CCD カメラ(30 fps)を用い て振動回転子の運動を上から撮影し，得られた画像を 解析し， $\beta$ を求めた。

図 4 に初期天頂角 $\theta_{0}=30 \mathrm{deg}$ としたときの回転角 $\beta$,

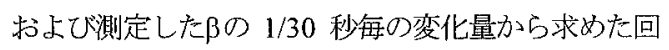
転角速度 $\Omega=\mathrm{d} \beta / \mathrm{d} t$ を示寸. 図から分かるように，振 動回転子を傾けてから離すと, 初め, 接地している脚 (以下, 軸脚と呼占)は, 脚 $\mathrm{P} \rightarrow \mathrm{Q} \rightarrow \mathrm{R} \rightarrow \mathrm{Q} \rightarrow \mathrm{P} \rightarrow \mathrm{Q} \cdots$ と 順次切り替わりながら回転し，やがて振動が収まり，

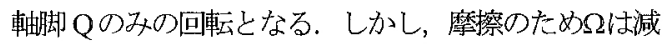
少する，早存与えることにより，初期位置エネルギ 一が，回転工ネルギーに変換されていることが分かる. 図4には，4章で述べる解析結果も示されており，実 


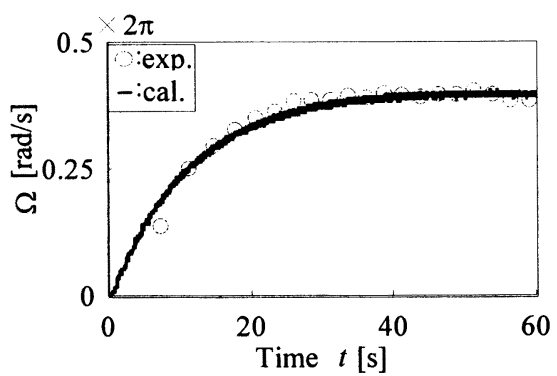

Fig.6 Transient response of an oscillatory rotor excited at $f_{e x}=6 \mathrm{~Hz}\left(S=40 \mathrm{~mm}, A_{e x}=0.5 \mathrm{~mm}\right)$

験結果とかなりよく一致している.

次に図 5 に示すように, 中央の脚 $\mathrm{Q}$ の先端が接触す る床面のみを加振機により変位加振した. 脚 $\mathrm{P}, \mathrm{R}$ の 先端は固定した台上で接地する. 軸脚と加振機先端の 運動の測定には, 高速度カメラ(125fps)を用いた.

変位加振された振動回転子の各脚の先端は, 台や加 振機先端と接したり離れたりを繰り返す. 加振变位お よび振動数が適切であれば，振動回転子は規則的な運

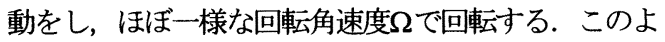
うな回転を以下では，定常的な回転と呼ぶ．定常的な 回転が生じたときの $\Omega$ 時間変化を図 6 に示寸. 一定 の振動を与え続けると, 約 40 秒で, 回転角速度 $\Omega$ ほぼ一定となることが分かる. 図には，次章で述べる 計算結果も示してあるが，よく一致している. なお, 実験において, 加振変位の変動は大きいときでも $10 \%$ 以下であった.

\section{4. 解 析}

振動回転子を剛体とみなし，接地点を運動の原点と する振動回転子に固定した座標系で考える. 軸脚の先 端と台上面との接地点は滑らないとすると，振動回転 子の運動方程式は次のように表せる.

$$
\delta \vec{L} / \delta t+\vec{\omega} \times \overrightarrow{\boldsymbol{L}}=\vec{N}-\vec{D}
$$

ただし， $\boldsymbol{L}$ は軸却先端まわりの振動回転子の角運動量, $\vec{\omega}$ は空間固定座標系 $X Y Z$ に対する物体固定座標系の 角速度を表す. 物体固定座標系は, 軸脚が $\mathrm{Q}$ のとき は C- $\xi \eta \zeta ，$ 軸却が P あるいは R のときはそれぞれの 脚先端を原点とし, 三つの座標軸は $\xi, \eta, \zeta$ 軸と平行 にとる. 角運動量 $\vec{L}$ は慣性テンソルクを用いて，

$$
\overrightarrow{\boldsymbol{L}}=[\boldsymbol{I}] \overrightarrow{\boldsymbol{\omega}}
$$

と表せる. ただし，物体固定座標系において[I]成 分は，付録に示すように床と接する脚によって異なる.
式(1)の左辺第一項は, 物体固定座標系における $\overrightarrow{\boldsymbol{L}}$ の

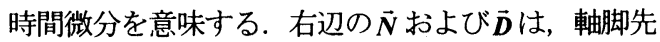
端まわりの重力によるトルクおよび摩擦トルクを表す.

振動回転子の中央の脚 Q が接地しているときのみ, 鉛直方向に,

$$
\left(A_{e x} \sin \omega_{e x} t\right) \overrightarrow{\mathbf{e}}_{z}
$$

で変位加振されるので, 軸脚が $\mathrm{P}, \mathrm{Q}, \mathrm{R}$ の場合の $\vec{N}$ を $\vec{N}_{P}, \vec{N}_{Q}, \vec{N}_{R}$ とすると, 次のように表せる.

$$
\left\{\begin{array}{l}
\vec{N}_{P} \\
\vec{N}_{Q} \\
\vec{N}_{R}
\end{array}\right\}=-M g\left\{\begin{array}{c}
\vec{r}_{P G} \times \overrightarrow{\mathbf{e}}_{z} \\
\left.\left[1+\left(A_{e x} \omega_{e x}^{2} / g\right) \sin \omega_{e x} t\right] \vec{r}_{Q G} \times \overrightarrow{\mathbf{e}}_{Z}\right\} \\
\vec{r}_{R G} \times \overrightarrow{\mathbf{e}}_{Z}
\end{array}\right\}
$$

ここで, $M$ は振動回転子の質量， $g$ は重力加速度, $A_{e x}$ は加振振幅, $\omega_{e x}$ は加振角振動数, $\overrightarrow{\mathbf{e}}_{z}$ は空間に固 定された $Z$ 軸の単位べクトル， $\vec{r}_{P G}, \vec{r}_{Q G}, \vec{r}_{R G}$ はそ れぞれ軸脚 $\mathrm{P}, \mathrm{Q}, \mathrm{R}$ の先端から重心 $\mathrm{G}$ へのベクトル である.

式(1)の摩擦トルク $\overrightarrow{\boldsymbol{D}}$ は実験的に求めた． $\xi, \eta$ 軸ま わりの微小振動より, これらの軸まわりの摩摖トルク は, 角速度に比例する粘性減衰 $c_{\xi} \omega_{\xi}, c_{\eta} \omega_{\eta}$ で近似し た. 軸まわりの回転運動をさせたときの挙動から, 軸まわりの摩擦トルクは回転速度に無関係な一定の 摩擦トルク $D_{\zeta}$ が作用するとした. すなわち，

$$
\overrightarrow{\boldsymbol{D}}=\left[\begin{array}{lll}
c_{\xi} \omega_{\xi} & c_{\eta} \omega_{\eta} & \operatorname{sgn}\left(\omega_{\zeta}\right) D_{\zeta}
\end{array}\right]^{\mathrm{T}} \quad \cdots(5)
$$

軸脚の切り替わりは, 瞬間的に起こるとし, 脚の切 り替わる前後で, 軸脚先端まわりの角運動量は保存さ れるとした. すなわち, 切り替わる直前の角速度を $\vec{\omega}$, 直後の角速度を $\vec{\omega}^{\prime}$ とすると, 例えば, 軸脚が脚 $\mathrm{P}$ から脚 $\mathrm{Q}$ に替わる場合

$$
\left[I_{Q}\right] \vec{\omega}^{\prime}=\left[I_{G}\right] \vec{\omega}+M \vec{r}_{Q G} \times\left(\vec{\omega} \times \vec{r}_{P G}\right)
$$

となる. ここで, $\left[\boldsymbol{I}_{G}\right]$ は重心 $\mathrm{G}$ まわりの慣性テンソル を表し，その成分は次のようになる.

$$
\left.\begin{array}{l}
I_{\xi \xi}=I_{\xi G}, \quad I_{\eta \eta}=I_{\eta G}, \quad I_{\zeta \zeta}=I_{\zeta G} \\
I_{\eta \zeta}=I_{\zeta \eta}=0, \quad I_{\zeta \xi}=I_{\xi \zeta}=0, \quad I_{\xi \eta}=I_{\eta \xi}=0
\end{array}\right\} \text { (7) }
$$

また，他の脚の切り替わりについても同様で，例え ば，軸脚が脚 $\mathrm{Q} か ら$ 脚 $\mathrm{R} に$ 替わる場合には，式(6)で $\mathrm{P}$ Q，QをRにすればよい．

本解析では，空間固定座標系に対する物体固定座標 系の向きを，オイラ一角 $\theta ， \varphi ， \psi$ を用いて表し(4)，こ れら三個の変数について式(1)を数値積分し, 時刻歷 応答を求めた。 


\section{5. 結果および考察}

振動回転子の回転角速度 $\Omega$ にぼす加振振動数 $f_{e x}$ の影響を図 7 に示す。図中の○印は定常回転したこと を示しており，繸の点線で示した寒験結果は， $\xi ， \eta$ 軸まわりの振動が大きくなり，回転が止まりそうにな ったり，速くなったりして定常回転しなかったことを 示卞. $f_{e x}=5.5 \mathrm{~Hz}$ て住，定常回転(○印)するとき之， 定常回転しない(点線)とざがあった。図には，時刻歴 応答の計算により，定常回転する結果の得られた $\Omega$ も 示されている，実験結果とは，かなりよい一致を示し ている，ただし，実験では，定常回転しなかった $f_{e x}=12.5 \sim 14 \mathrm{~Hz}$ の範囲でも, 計算では定常回転する結 果が得られた。

図7の定常回転する三つの範囲で，それぞれ最も速 く回転する $f_{e x}=3,6,11.5 \mathrm{~Hz}$ にお引ける振動回転子の 挙動と加振機先端の变位 $u_{e x}$ を図 8 に示す．図には振 動回転子の運動の二周期分を示寸。图 8(a)上図は $\eta$ 軸方向から見た振動回転子の運動之加振機先端の動 きを模式的に示したものであり，上図中の(1などは， 図 8(a)下図の(1)などと対応している. 図 8(a) 上図の 脚先の○印は加振機先端あるい恃固定台に振動回車云子 の当該の脚が接していることを示す，図 8(a)下図に 示すように $f_{e x}=3 \mathrm{~Hz}$ では, 振動回転子の脚怯，若干の 位相ずれはあるが，加振機先端が上向きに運動すると き性順に $\mathrm{P} \rightarrow \mathrm{Q} \rightarrow \mathrm{R}$ と切り替わる(図中(1)〜(5)五)，下 向きに運動するときには脚 $\mathrm{R} か ら$ 中央の脚 $\mathrm{Q}$ を飛び 越えて脚 $\mathrm{P}$ に切り替わる(図中(6) (8)，以下この運動 が繰り返される、すなわち，加振機先端の運動が一周 期の間に振動回転子の運動も一周期である.この連動 をパターンAと呼ぶことにする.

図8(b)は， $f_{e x}=6 \mathrm{~Hz}$ のとさで，振動回転子が二周期 運動する間に, 軸脚は $\mathrm{P} \rightarrow \mathrm{Q} \rightarrow \mathrm{R} \rightarrow \mathrm{Q} \rightarrow \mathrm{P}$ と順番に切 り替わり連動一周期の間に加振機先端は 2 回振動する。

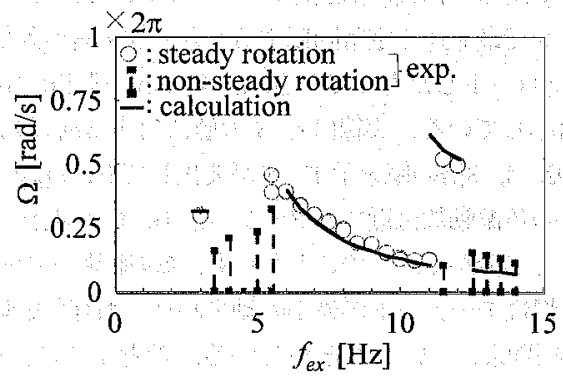

Fig.7 Effect of exciting frequency $f_{e x}$ on rotational angular speed $\Omega\left(S=40 \mathrm{~mm}, A_{e x}=0.5 \mathrm{~mm}\right)$
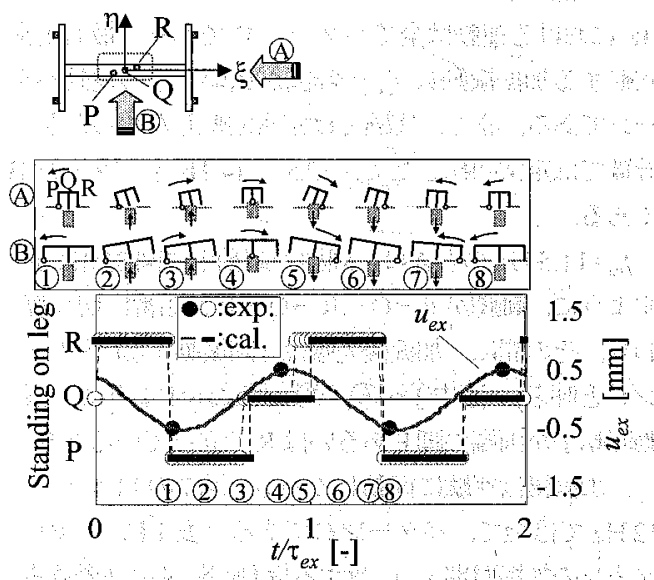

(a) Pattern $\mathrm{A}\left(f_{e x}=3 \mathrm{~Hz}\right)$

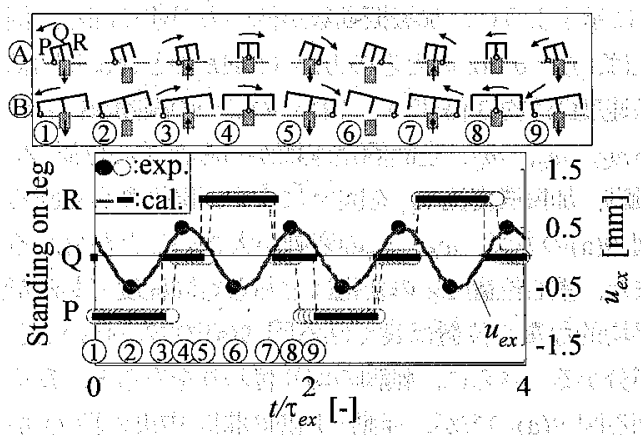

(b) Pattern B $\left(f_{e x}=6 \mathrm{~Hz}\right)$

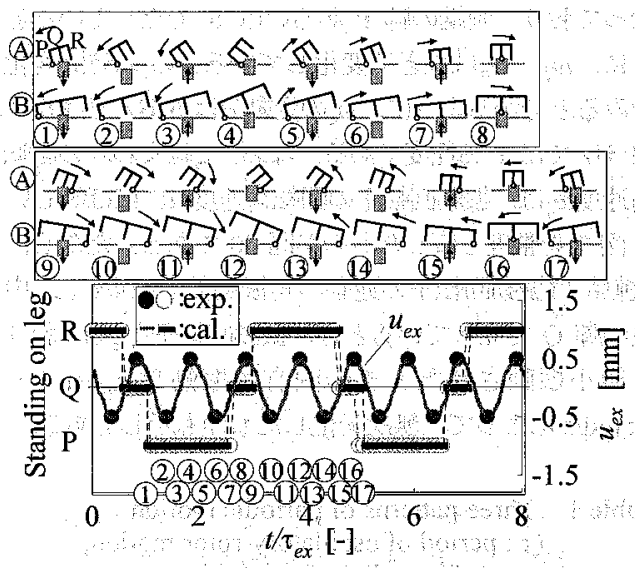

(c) Pattern $\mathrm{C}\left(f_{e x}=11.5 \mathrm{~Hz}\right)$

Fig. 8 Periodic motions of an oscillatory rotor for three values of exciting frequency $f_{e x}$ $(S=40 \mathrm{~mm})$ 
この運動をパターン $\mathrm{B}$ と呼ぶ. 図 7 の $f_{e x}=6 \sim 11$ $\mathrm{Hz}$ における運動は全てパターン B であり, 最も定常 回転する加振振動数 $f_{e x}$ の範囲が広いときの運動パ夕 ーンである. また，実験では定常回転しなかったが， 計算では定常回転した $f_{e x}=12.5 \sim 14 \mathrm{~Hz}$ もパターン B である.

$f_{e x}=11.5 \mathrm{~Hz}$ のときは一周期の運動中に図 $8(\mathrm{c})$ に示 すように, 軸脚が $\mathrm{P} \rightarrow \mathrm{Q} \rightarrow \mathrm{R} \rightarrow \mathrm{Q} \rightarrow \mathrm{P}$ と順番に切り替 わり,その間に, 加振機先端は4回振動する(パター ン C と呼ぶ). 図中(1)〜 (6), (10)〜(15)に示すように, 振 動回転子が両端の脚PあるいはRで立つているとき に，加振機は無駄に振動している. 図7の11.5〜 $12 \mathrm{~Hz}$ では全て, パターンCである. 表 1 に三つのパ ターンの加振周期 $\tau_{e x}$ に対寸る振動回転子の運動周期 ての比をまとめて示す.

$f_{e x}=6 \sim 11 \mathrm{~Hz}$ ではパターン B の運動をするが, 図 7 に示すように, 加振振動数が低い万が速く回る. 例 えば, $f_{e x}=6 \mathrm{~Hz}$ のときの方が $11 \mathrm{~Hz}$ のときより回転 角速度 $\Omega$ は約 3 倍速い. これらの二つの振動数におけ る $\omega_{\xi}, \omega_{\eta}, \omega_{\zeta}$, 空間固定座標加みた重心位置 $Z_{G}$, 軸脚，加振機変位 $u_{e x}$ を図 9 に示す. 図より良く回る 図 9(a)の方が， $\omega_{\xi}, \omega_{\eta}$ の変動が大きいことが分かる. また, 重心位置 $Z_{G}$ の変化はどちらも同程度であるが, 平均的な重心位置は良く回る図 9(a)の方が高いこと が分かる.さらに, 軸脚の切り替わりをみると, 良く

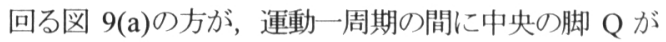
軸脚となっている時間的割合が短い! また, 中央の脚 $\mathrm{Q}$ で立っているとき $\omega_{\xi}, \omega_{\eta}$ は極大，あるいは極小と なっており, 両端の脚 $\mathrm{P}$ あるいは $\mathrm{R}$ で立っていると きに, $\omega_{\xi}, \omega_{\eta}$ は大きく変化している. $\omega_{\zeta}$ の時間変化 をみると分かるように， $\omega_{\zeta}$ 変動分は $6 \mathrm{~Hz}$ では $6 \%$,

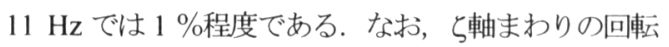

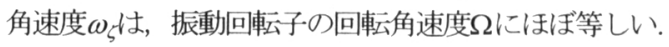

図 7 を整理し直したものが図 10 である。ただし, 縦軸には振動回転子の運動の角振動数 $\omega=2 \pi / \tau$ を, 中 央の脚 Q で立っているときに振動回転子を軸まわり に微小振動させたときの固有角振動数 $\omega_{n \xi}=1.4 \times$ $2 \pi \mathrm{rad} / \mathrm{s}$ によって, 無次元化したものも示してある.

Table 1 Three patterns of periodic motion ( $\tau$ : period of oscillatory-rotor motion, $\tau_{e x}=1 / f_{e x}:$ period of excitation)

\begin{tabular}{c|c}
\hline Pattern & $\tau / \tau_{e x}$ \\
\hline $\mathrm{A}$ & $1 / 1$ \\
\hline $\mathrm{B}$ & $1 / 2$ \\
\hline $\mathrm{C}$ & $1 / 4$ \\
\hline
\end{tabular}

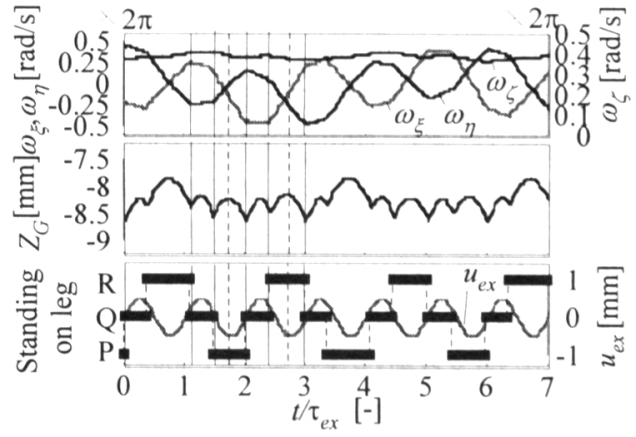

(a) $f_{e x}=6 \mathrm{~Hz}$

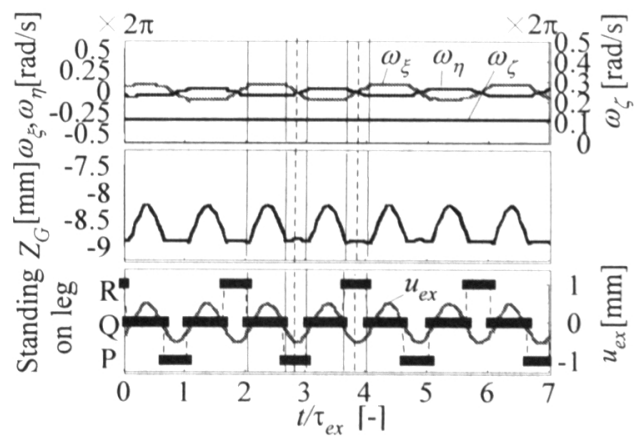

(b) $f_{e x}=11 \mathrm{~Hz}$

Fig.9 Effect of exciting frequency $f_{e x}$ on the motion in Pattern $\mathrm{B}(S=40 \mathrm{~mm})$

○印の大きさが回転角速度 $\Omega$ の速さを表している. 図 から運動の角振動数比 $\omega / \omega_{n \xi} \fallingdotseq 2$ で良く回転し, その ときの加振角振動数比 $\omega_{e x} / \omega_{n \xi}$ はパターン $\mathrm{A}$, パター ン $\mathrm{B}$ ，パターン $\mathrm{C}$ でそれぞれ $2 ， 4 ， 8$ であることが分 かる. パターン B では, 加振角振動数 $\omega_{e x}$ が増加する と連動の角振動数 $\omega$ も $\omega=\omega_{e x} / 2$ の関係を保つて増加し, 回転角速度 $\Omega$ は堿少している。これから軸まわりの 固有角振動数 $\omega_{n \xi}$ が，振動を回転運動一変換させるこ とに関係していると考えられる.

$S$ を変えると, $\omega_{n \xi}$ も変化する。眓11はそれぞれの パターンで最も速く定常回転するときの加振角振動数 $\omega_{e x}$ をプロットしたものである. $S=40 \mathrm{~mm}$ が図10の結

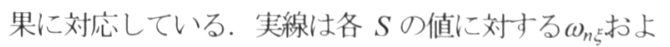
びその2，4，8倍の值を示す． $S$ が変化しても， $\omega_{n \xi}$ の2, 4, 8倍の角振動数付近でパターン A， B，C が現れて いることが分かる、このことからも, 振動回転子の運 動は，慣性モ一メントが最小の軸まわりの固有角振動 数 $\omega_{n \xi}$ と関係していることが分かる．参考までに， 軸まわりの固有角振動数 $\omega_{n \eta}=0.6 \times 2 \pi \mathrm{rad} / \mathrm{s}$ であり, 運動変換にはあまり関係がないと考えられる。 


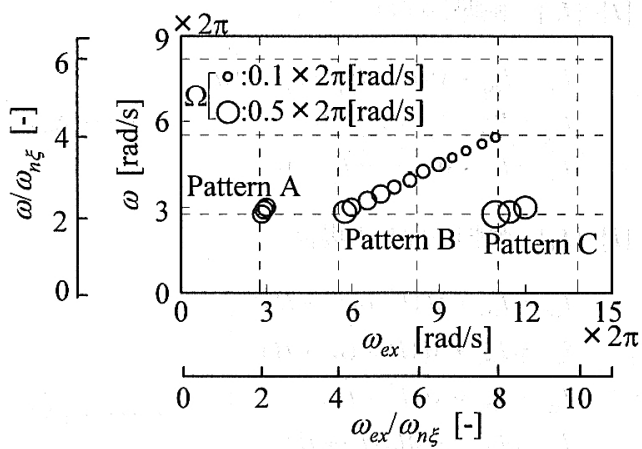

Fig.10 Effect of $\omega_{n \xi}$ on $\omega$ and $\omega_{e x}$

(Calculated results; $S=40 \mathrm{~mm}, A_{e x}=0.5 \mathrm{~mm}$, $\omega_{n \xi}=$ angular frequency about the $\xi$ axis)

次に，振動回転子の軸まわりの運動が，回転運動 八変換される原理について考える. 漸まわりの運動 で, 軸却が $\mathrm{Q}$ から $\mathrm{P}$ 人切り替わるときの運動を $Y Z$ 平 面と $X Y$ 平面に投影して示したのが図 12 である.

印は脚先端を示し， 印は軸脚先端を示す. 図 12(a) から(b)に示すように，振動回転子が $Y Z$ 平面で時計ま わりに回転して，軸脚が Q から P 切り替わると重 心位置は接地面より低いので, 慣性力 $F_{Y}$ は $Y$ 方向に 作用し，振動回転子を反時計まわりに回転させようと する. 軸却が Q から R 切り替わるときも同様で, これが，軸まわりの振動を軸まわりの回転に変換 するメカニズムである.

パターン Bで定常回転するとき, 図9から分かるよ うに軸脚が $\mathrm{Q}$ に切り替わるとき，角速度 $\omega_{\xi}$ は極大あ るい㥛小で, 重心位置 $Z_{G}$ は上向きに持ち上げられ ている. また, 図 8 より, パターン $\mathrm{B}, \mathrm{C}$ の運動のと きも同様なことが言え, 変位加振によって振動回転子 は, パラメータ励振と同様なメカニズムで振動が起こ り,この振動が振動回転子の特性で回転運動に変換さ れていると考えられる.

振動回転子の回転角速度 $\Omega$ と集中質量の位置 $S$, 寸 なわち，慣性モーメントとの関係を図 13 に示す，定 常的な回転䡣動に変換されるときの加振振動数の範囲 が最も広いパターン Bで, 最も速い回転角速度 $\Omega$ と のときの $f_{e x}$ を $S$ に対して示している. $I_{\zeta G}$ と $I_{\eta G}$ が接 近する $S=20 \sim 25 \mathrm{~mm}$ 付近で $\Omega$ が最も速くなり，振動 を回転へ回生させるのに良い関係があることが分かる.

\section{6. 結 論}

振動回転子を上下に変位加振したときの挙動を実験 的, 理論的に考察し, 加振振動数が適切な範囲にあれ

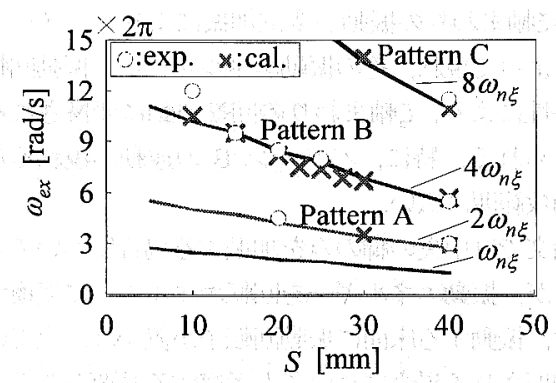

Fig.11 Relation between Patterns of motion and $\omega_{n \xi}$ $\left(A_{e x}=0.5 \mathrm{~mm}\right)$

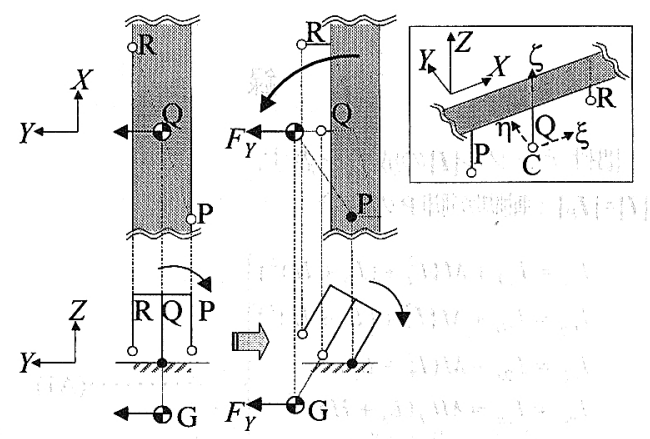

(a) (b)

Fig.12 Inertial force $F_{y}$ causing rotation in switching from pivoting leg $\mathrm{Q}$ to $\operatorname{leg} \mathrm{P}$

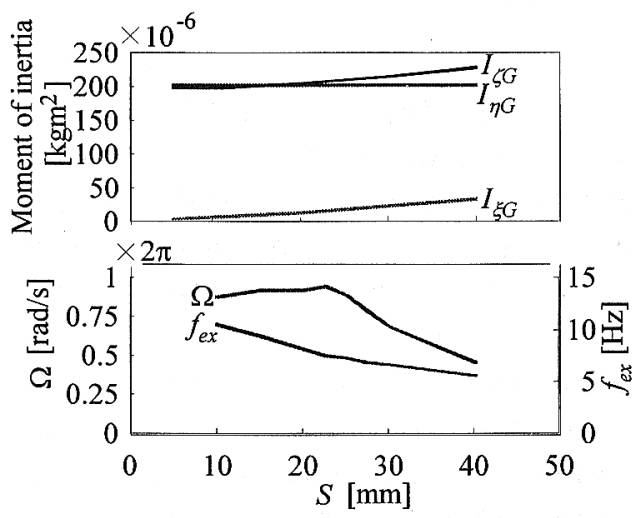

Fig.13 Effect of $S$ on $\Omega$

(Calculated results; Pattern B, $A_{e x}=0.5 \mathrm{~mm}$ )

ば，振動回転子が定常回転することを明らかにした。 その適切な加振振動数とは，振動回転子の慣性モ一メ ントが最小の軸まわりに中央の脚のみで立って微小 振動したときの固有角振動数 $\omega_{n \xi}$ の $2 ， 4 ， 8$ 倍の振動数 付近である. そのとき振動回転子の運動の周期は加振 周期のそれぞれ，1，2，4倍である．振動回転子の運 
動は，軸まわりの振動が変位加振によりパラメータ 励振によって現れ，その振動エネルギーが，振動回転 子の特性により，軸まわりの回転運動に変換される と考えられる. 特に, パターン B の運動が現れる加 振振動数範用は広い.

本論文では中央の脚のみを加振する場合について考 察したが，振動エネルギーを回転エネルギーに変換す るには，振動する床面に振動回転子が置かれ，全ての 脚が加振される場合についても考察する必要がある.

また, エネルギーの変換効率については今後の検討課 題である.

\section{付 録}

慣性テンソル【のの成分を表す。

$[\boldsymbol{I}]=\left[\boldsymbol{I}_{\boldsymbol{P}}\right]$ : 軸却が脚 $\mathrm{P}$ の場合

$$
\left.\begin{array}{l}
I_{\xi \xi}=I_{\xi G}+M\left\{L_{2}^{2}+\left(L_{3}+H\right)^{2}\right\} \\
I_{\eta \eta}=I_{\eta G}+M\left\{L_{1}^{2}+\left(L_{3}+H\right)^{2}\right\} \\
I_{\zeta \zeta}=I_{\zeta G}+M\left(L_{1}^{2}+L_{2}^{2}\right) \\
I_{\eta \zeta}=I_{\zeta \eta}=M L_{2}\left(L_{3}+H\right) \\
I_{\zeta \xi}=I_{\xi \zeta}=M L_{1}\left(L_{3}+H\right) \\
I_{\xi \eta}=I_{\eta \xi}=-M L_{1} L_{2}
\end{array}\right\}
$$

$[I]=\left[I_{Q}\right]:$ 軸脚が脚 $\mathrm{Q}$ の場合

$$
\left.\begin{array}{l}
I_{\xi \xi}=I_{\xi G}+M H^{2}, \quad I_{\eta \eta}=I_{\eta \sigma}+M H^{2} \\
I_{\zeta \zeta}=I_{\zeta G}, \quad I_{\eta \zeta}=I_{\zeta \eta}=0 \\
I_{\zeta \xi}=I_{\xi \zeta}=0, \quad I_{\xi \eta}=I_{\eta \xi}=0
\end{array}\right\}
$$

$[\boldsymbol{I}]=\left[\boldsymbol{I}_{\boldsymbol{R}}\right]:$ 軸脚が脚 $\mathrm{R}$ の場合

$$
\left.\begin{array}{l}
I_{\xi \xi}=I_{\xi G}+M\left\{L_{2}^{2}+\left(L_{3}+H\right)^{2}\right\} \\
I_{\eta \eta}=I_{\eta G}+M\left\{L_{1}^{2}+\left(L_{3}+H\right)^{2}\right\} \\
I_{\zeta \zeta}=I_{\zeta G}+M\left(L_{1}^{2}+L_{2}^{2}\right) \\
I_{\eta \zeta}=I_{\zeta \eta}=-M L_{2}\left(L_{3}+H\right) \\
I_{\zeta \xi}=I_{\xi \zeta}=-M L_{1}\left(L_{3}+H\right) \\
I_{\xi \eta}=I_{\eta \xi}=-M L_{1} L_{2}
\end{array}\right\}
$$

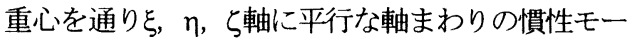
メントを $I_{\xi G}, I_{\eta G}, I_{\zeta G}$ とする. ここで, 軸脚が脚 $\mathrm{Q}$ の場合, 慣性乗積は非常に小さいとして無視している.

\section{文献}

(1) Walker,G.T., Q.J.Pure Appl.Math.,28(1896),175.

(2) Walker,J., Scientific American, 241(1979), 144.

(3) Bondi,H., Proc.Roy.Soc.Lond.,A405(1986),265.

(4) 中野健 - 佐藤勇一・後藤孔明・二瓶泰治, 機論, 66-641, C(2000), 9-15. 